\title{
HELPING OTHERS THROUGH A VIRTUAL COMMUNITY (Communication Pattern of Smog Problems by Bebas Asap Volunteers)
}

\author{
Ratna Permata Sari \\ Universitas Islam Indonesia, Yogyakarta, Indonesia \\ Email: ratna.permatasari@uii.ac.id
}

\begin{abstract}
Smog problems from forest fireshappened in Indonesia almost every year during the dry season. The case of forest fire in 2015 is one of the biggest forest fire in Indonesia which brought big impacts for health of human, enviroment and social aspects. In health aspect, the smog caused the limited visibility, and serious health problems such as respiratory diseases. It needs huge social awareness and participation from the government and society to help the victims of smog. With this situation, volunteers from TurunTanganused online news portals, such as www.bebasasap.org that aimed to spread the latest information from smog area. From that background, researchers were interested in studying about communication patterns in the BebasAsap community in their spread of information and raising donations to fulfill the need of victim smog disaster. Communication pattern in this virtual community delivered three approaches: (1) Analysis of interation among core members of BebasAsap community with external parties very intense. (2). The hierarchy of communication in this community used two ways, horizontal and diagonal communication. (3). This social community, especially in core members of bebasasap community, used all channel communication network structures because all of the core members have the same position and power in decision making based on their own job description.
\end{abstract}

Keywords: Communication Pattern, Smog, Virtual Community.

\section{Background Problems}

In 2015, a forest fire occurred in Sumatra and Kalimantan, which caused a great impact and were significant for the residents. Emergency of smog cannot be underestimated, even haze of smoke is considered as the biggest disaster in the last 10 years. Smog that blanketed Sumatra and Kalimantan has disrupted the activity of citizens, businesses, and airlines. On September 4, 2015, the Ministry of Environment and Forestry noted that there are 156 point source heat haze in Sumatra and Kalimantan. From these 156 points, 95 pointsin Sumatra and 61 points in Kalimantan. Particularly, dense smog blanketed the region of South Sumatra, Jambi, Riau, West Kalimantan, Central Kalimantan and South Kalimantan. The smog has also spread to a number of areas in six provinces. In Sumatra, haze blanketed 80 percent of its territory. At least as many as 25.6 million people are exposed to smoke, that 22.6 million people in Sumatra and 3 million people in Kalimantan (Kabutasapsudahdarurat, 2015).

Smog that spread in some areas caused serious health problems. Disaster victims haze in Sumatra and Kalimantan continues to grow. According to the Head of Data Information and Public Relations of National Disaster Management Agency (BNPB) SutopoPurwoNugroho, 10 people died in Sumatra and Kalimantan from both direct and indirect impacts (Reza, 2015). The direct impact is the victims who died in the fire and burned, while indirect victims sickened by fumes, or previously had a history of pain and the presence of smoke aggravate the pain. 
According to data BNPB, in six provinces since July 1 until October 23, the 2015 disaster of smog in the two islands has caused 503. 874 people experiencing Acute Respiratory Infections (ARI). Actually, the number of patients ISPA ismore than that because most people who are sick do not go to the health center or hospital, so the real number of victims is not recorded.

Walhi, Executive Director of the Indonesian Forum for the Environment, concludes that this cycle, which initially occurs every ten years, but became shortened to only seven years, is caused by a variety of factors such as Indonesia's worsening environmental situation and the impact of uncontrolled climate change.

Smog extends from Sumatra and Kalimantan to reach Malaysia, Singapore, Thailand, Philippines and Vietnam. This makes the effects of secondhand smoke a stronger pressure on Indonesia. This is what makes Indonesia finally "open the door" to accept the help of neighboring countries. There are five countries that help include: Singapore, Malaysia, Australia, China, and Russia (Bantuanmengatasiasap, 2015).

Aid goods come from various parties, from companies, NGOs and other social communities. The assistance provided ranges from: masks, oxygen, health checks by medispersonel, drugs, and so forth.

In this study, the researcher took the object of community research team of volunteers from the TurunTanganCommunity. The team of volunteers was initiated by PuadiAsrari. They saw that smoke problems are compounded by the lack of knowledge of society itself. This leads to wrong handlingby a lot of people during exposure and this results severe impacts, together with government involvement is also not enough, not to mention the lack of availability of information that can be easily accessed by the public about the smoke and the current condition of their area.

To expedite the work of Bebas Asap volunteers to be able to move quickly to help this haze problem, communication between teams becomes important and interesting to study. Especially considering that almost all of the members of the team of volunteers is not in one location that could allow their direct contacts face to face.

\section{Research Question}

Based on the background problems, can be drawn the problem formulation that is: "What is the communication pattern conducted by Bebas Asap volunteers asa virtual community to spread information and help smog victims?

\section{Literature Review}

New media studies is a study that can be considered new and will continue to grow with the continued development of ICT today. The relevant previous research among other study is entitled: "Online gaming group communication patterns" (virtual ethnography study on user games "Clash of Titans" Community I-ron) by Rio Ricky, RatihHasanahdanIndraN.A.Pamungkas.. The purpose of this research is to know the pattern of communication groups and the process of virtual interactions that occur within games online group communication "clash of clans" community I-ron. From the results, it can be concluded that the pattern of communication I-the clan clan namely I-ronron features the communication pattern "all channel" due to a match on the characteristics of communication that occur in a clan I-ron as well as communication that occurs are open, not restricted to the level of office of its members, and does not pass through intermediaries to provide information, so that communication happens very smoothly and there were no barriers(Ricky, 2015).

The second previous research is the Communication groups behaviour of Kaskus virtual community of Riau Raya Region by Nova Yohana and TikaWulandari. This study aimed to determine the role of communicator of the virtual group, the interchangeable messages, the 
interaction patterns, the unity and norms of group communication in Kaskus virtual community of Riau Raya Region in Pekanbaru. The result of the study showed that the member of Kaskus virtual community of Riau Raya has a role in accordance with the structure and the level of the post. As a forum for discussion and trading, the members of this community share information using Kaskus language as the group identity. Social interaction that exist in this community is not only happening in online communication, but also in offline communications (Yohana\&Wulandari, 2014, 117-128).

\section{Research Methodology}

The study was a descriptive study with qualitative approach and constructivism paradigm. Qualitative research seeks to understand an event through knowledge. The object of this study is volunteers of Bebas asap action. For data collection techniques are observation, indept interview and litetature review. In this study, respondent selection technique is purposive sampling where researchers had previously select respondents based on several considerations are of course tailored to the needs of research data. Researcher conducted interviews with two respondents such as AsrariPuadi as Project Leader of bebasasap action and RizkaAmaliaShofa as coordinator of fund raising and educational content manager.

\section{Analysis}

\section{Community-based Virtual Group Communication}

Virtual communication by Bebas Asap volunteer team is the fulfillment of the basic criteria in the formation of virtual communities such as: a minimum level of interaction which provides a free website platform to be able to communicate with external parties what victims of smoke need. At this level, providing a platform for communication alone is included in the minimum level of interaction. Especially in this group, there is a fairly intense communication interaction in the team of Bebas Asap volunteers themselves with a team of volunteers from TurunTangan from various regions and external parties that include smoke victims and outside communities residing in the area. And it has complemented the second basic criterion of the diversity of communicators in which the virtual community must consist of diverse participants (Nasrullah, 2015, p. 111).

For public space as a medium of interaction there are two platforms, first is the online messaging team Bebas Asap volunteers where they use social media platform Line and Hangout to communicate and coordinate directly from fundraising, filling the website content to the donation of donations to the disaster area. The second platform is the website www.bebasasap.org. In the website, there is a space calledSmoke Free Help Center (Pusat Bantuan Bebas Asap) which becomes a forum to inform the needs of victims of smoke and update the situation of the area information. This forum can be accessed by anyone who wants to provide assistance.

The existence of public space is very important considering the team of Bebas Asap volunteers are not in one region, there are in Jakarta, Yogyakarta and Surabaya. But they have to determine their cyberspace through online messaging, through this forum they communicate regularly as required of this smoke free movement. Bebas Asap websites is useful for medium of information to a wide audience, there is also a space Smoke Free Help Center where people can post about the help.

Related to the quality of virtual communities, the first aspect is the external factor. The seven BebasAsapvolunteers originally came from Turun Tangan volunteers who had previously met face-to-face meetings once in Jakarta. So, it makes it easier for them to communicate through online messaging because it has never met before. For temporal structures, communicating synchronously means that communication is done in real time through online messaging, this is done by a team of Bebas Asap volunteers in the chat forum on the Line. While asynchronous messages are already delayed (not real time) on the website www.bebasasap.org in space Pusat Bantuan Bebas Asap where where people can write down the needs of donations, and it is also delayed and can be saved as a database. 
There is always a goal of community building, in which case the aim is to help the victim smoke. Due to distance apart, volunteers use forums on social media online and smoke free websites. Both platforms aim to facilitate communication, coordination with other BebasAsapvolunteers and interaction with other communities or mass media for the need for information dissemination of this smoke disaster. There is a common interest for this social action, adding aspects of quality improvement in terms of the characteristics of the group and its members.

As described above on the basic criteria and quality improvement of the BebasAsapvirtual community according to Quentin Jones, written in the Journal of Computer Mediated Communication(Wood \& Smith, 2005, p. 129), it agrees with Van Dijk's table on digital community networks: use and involvement explaining virtual communities must have aspects Such aspect as exposure and use is the interactivity in Line online messaging by smoke free volunteers and website platform www.bebasasap.org to request donations and information, functionality of the BebasAsapvirtual community to help victims of smoke from fundraising, information dissemination Disasters of smoke and distribution of aid to the right areas.The last aspect is involvement. The explanation of this participation is felt when entering in the coordination stage for fundraising and aid distribution. Fund raising involving relationships with TurunTangan community so that information can be socialized more effectively. As well as to update information from the disaster location also involves members of the TurunTangan who are in the vicinity of the location, especially for the distribution of aid to the region also involves the community in that location.

\section{Analysis of the Approach of Group Communication Patterns. a) Interaction Analysis}

Interaction analysis is needed to analyze interaction among group members. The first can be seen from the intensity of communication. In virtual communities this BebasAsapvolunteerteam communicates quite intensely through LINE messaging and Hangouts. Especially considering their purpose is to help victims of smoke so that the intensity of communication must be very large because the moment events that require to respond quickly. As described above, the election of BebasAsapteam volunteer members who are only seven people although separated in several cities in Indonesia, they are better off working with people who can work quickly and fast communication response as well. How to communicate can be through LINE group or directly call if need discussion directly.

For its communication interaction, this community not only deals with fellow internal members, but also others, among others, Volunteer Down Hand across Indonesia to facilitate the dissemination of information, media workers, donors and other NGOs located in disaster areas that will channel assistance directly to victims smoke. Compared with others, the intensity of BebasAsapvolunteer communication is most often with fellow Down Hand volunteers. While not joining in this action, their contributions are enormous. Starting from the beginning of the formation of this community, then the BebasAsapvolunteers also utilize the network of volunteer friendship TurunTangan who has volunteers up to more than 50,000 scattered throughout Indonesia. This is done to disseminate information about the existence of this smoke free action and also the website platform www.bebasasap.org which can be a container to distribute donations and current information from disaster areas.

For the duration of communication interaction as Bebas Asap volunteer, they can be said quite short, about two to three months. This community is active only when there are smoke disasteron the island of Borneo and Sumatra in mid-2015.

In interaction analysis, the second emphasis is the purpose of communication and with whom we communicate. The purpose of communication in this community is to help victims of smoke. The way to disseminate the right information to the public, one of them through the website www.bebasasap.org which provides content about the current state of the 
disaster area, what help is really needed and which areas have not gained the reach of assistance from the government or other parties.

Looking at the above goals so it needs to be mapped with whomever this community communicates. First, intense communication must be established within the Bebas Asap volunteers whichconsist of seven members. Secondly, with the Turun Tanganvolunteers scattered throughout Indonesia that facilitate the dissemination of information and fundraising. Third is the mass media that is certainly very contributing in the dissemination of information on this website www.bebasasap.org. Fourth is communication with members of the Turun Tangan who are in the area of exposure to smoke, where they are asked for help to update the latest information and also to channel immediate relief to smoke victims. Fifth is communication with other parties in the disaster area of the smoke, among others local NGOs.

The third interaction analysis is about who moves who and in what way. In this case, it starts from one of the Volunteers down in Borneo who tells the situation in the area that there is a fire and the effects of smoke that has disturbed everyday life. From this point, seven people who were concerned about the issue created a Bebas Asap volunteer team.

This community is formed because of the basis of social action, and there is also no strict organizational structure, so the question of who moves anyone becomes very flexible. Social concerns are mobilizing this volunteer team to make this community to both care for the smoke victims. How to send email blast to all members of the Turun Tangan movement throughout Indonesia to disseminate information and raise funds to donate this smoke relief. In addition, by way of website www.bebasasap.org which is expected to be accessible in general and easy. Installation of photos on the website is also selected which could attract attention and social awareness.

\section{b) Hierarchy of Communication}

In the volunteer community, this BebasAsapaction is using two-way communication where communication takes place between the two sides and there is a reciprocal relationship both from communicators and communicants. The two-way communication can occur vertically, horizontally and diagonally. In this case, this BebasAsapvolunteer community communicates horizontally and diagonally. They arenot communicating vertically because there is no strict organizational structure where there is usually a structure of chair, board and members. Although the naming of the task there is a project leader, but the person does not necessarily have higher authority than others members, especially in decision making because every member has own particular tasks.

That is why this type of communication horizontally is more appropriate to be used by this volunteer community because communication is established between communicator and communicant who have the same level, position and authority. In this case, each of the seven BebasAsapvolunteers has equal standing to express opinions, make decisions jointly. Even for some very special things for example to design smoke free website, web developer (web developer) do not need to report and ask project leader and other friends because it is given full authority by team to manage the website.

This community also performs diagonal communication where communication occurs between communicator and communicant whose level of position and authority is different. In this case the communicator in question is BebasAsapvolunteers and communicant is the outside party. For example, with Turun Tangan volunteers who do not join in this smoke free action. Although it used to be a communication before because both joined in the Turun Tangan movement but cannot be denied that they are external party who has a different position and authority.

Not about lower or higher positions, but because they are parties outside BebasAsapvolunteers who can not organize this action workflow. Among other external parties mentioned above in the sub-chapter of interaction analysis, diagonal communication 
between Bebas Asap volunteers and Turun Tangan volunteers is very intense and even biased if it is said who becomes communicator and communicant. That's because often the first volunteers who provide update information about the area and the victim of smoke. In addition, Bebas Asap volunteers also communicate with other agencies in the disaster area of the smoke to facilitate the process of providing assistance. One of them with Nurse Care Jambi where the agency is channeling the donation of phase three in the form of cash to conduct free medical treatment to the victims of smoke.

\section{c) Communication Network}

The communication network is a depiction of "how say to whom" in a social system. Devito (2011, p. 382) defines a communication network as a specific channel that is used to forward messages from one person to another.

Networks in groups and organizations can regulate the flow of information, bring together people of equal interest, form the same interpretation, increase social influence and allow for the exchange of resources. In a group and organization, an individual creates and exchanges messages with other individuals (Mahatir: 2015, p. 8).

From the structure of the communication network, BebasAsap volunteer community is more appropriate to use the all-channel network structure because in this structure all members have the same power to influence each other's members. Each member can communicate with other members because all channels in this network are open (Devito, 2011, p. 382). It is because in the practice of communication within this BebasAsapvolunteer community group, all members have the same position (no tiered structure) which can have the same power with each other.It is seen from the communication that exists that the use of LINE group messaging tends to be more relaxed. In addition, each of them has the same power in decision making in this action where each work in accordance with the job description so that when needed to make decisions in accordance with the division of tasks do not need to ask first to the other members.

\section{Conclusion}

Communicationsin BebasAsapvolunteer is based on virtual communities where more communication is established through CMC (computer mediated communication) and where a free website platform is available to communicate with external parties what victims of smoke need, for the seven volunteers themselves to communicate more Messaging Line, Skype and Hangout. They also did interactive communication with eksternal parties such asTurun Tangan Volunteer, media, donors and other NGO's located in disaster areas.

The presence of intense and interactive communication on the online messaging platform of the BebasAsap volunteer team itself among its seven members has become the minimum requirement of virtual community membership. Although BebasAsap community is a voluntary social community, it aims from the beginning to help victims of the smoke so that each of these seven people has a duty and responsibility. So, they are all active and share information among fellow team members.

The communication pattern in this community can be seen from three approaches: first seen from the analysis of the interaction of core members of BebasAsap volunteers who are very intense because of the small number and also with external parties who contribute in this action. As to who moves whom, because it is a social action so that it is social awareness to be with each other that moves these parties. Second from the communication hierarchy, the community uses two-way communication, horizontal communication and diagonal communication. Third seen from the communication network, this social action community uses an all-channel communication network structure where all members are equal and have the same strength. 


\section{References}

i. Bantuanmengatasi Asap, 2015. Bantuanmengatasi Asap. [Online] Available at: http://www.tempo.co/read/opiniKT/2015/10/13/11122/bantuan-mengatasiasap. [Accessed 20 September 2016].

ii. BuktiBencanaKabut Asap TahuniniTerparahSepanjang Sejarah, 2015. BuktiBencanaKabut Asap TahuniniTerparahSepanjang Sejarah. [Online] Available at: http://blog.act.id/2-bukti-bencana-kabut-asap-tahun-ini-terparah-sepanjangsejarah/ [Accessed 10 September 2016].

iii. Devito \& Joseph, A., 2011. KomunikasiAntarmanusia.EdisiKelima (terjemahan). Pamulang: Karisma Publishing Group.

iv. Dijk \& Jan, A., n.d. The Reality of Virtual Communities. [Online] Available at: https://www.utwente.nl/bms/vandijk/publications/the reality of virtual communi.pdf

v. Dijk \& Van., J. A., 2006. The Network Society: Social Aspects of New Media.. London: Sage Publications.

vi. Kabut Asap sudahDarurat., 2015. Kabut Asap sudahDarurat. [Online] Available at: http://print.kompas.com/baca/regional/nusantara/2015/09/05/Kabut-Asap-SudahDarurat[Accessed 10 September 2016].

vii. Muhammad, M., 2015. Pola Komunikasi Komunitas Laskar Sepeda Tua Pekanbaru Dalam Mempertahankan Solidaritas Kelompok. JOM FISIP, 2(2).

viii. Nasrullah \& Rulli., 2015. Media Sosial: Prosedur, TrendanEtika. Bandung: RemajaRosdakarya.

ix. Nova, Y. \& Tika, W., 2014. PerilakuKomunikasiKelompokKomunitas Virtual Kaskus Regional Riau Raya. JurnalPenelitianKomunikasi, 17(2), pp. 117-128.

x. Reza, 2015. Korban Kabut Asap di Sumatera dan Kalimantan terusBertambah. [Online] Available at: http://www.dream.co.id/news/korban-kabut-asap-di-sumatera-dankalimantanterus-bertambah-1510240.html[Accessed 10 September 2016].

xi. Rio, R., 2015. Pola Komunikasi Kelompok Game Online (Studi Virtual Etnografi pada pengguna game "Clash of Clans" Komunitas I-Ron). s.l.:Universitas Telkom.

xii. StrategiBebas Asap., 2015. StrategiBebas Asap. [Online] Available at: http://turuntangan.org/gerakan/bebasasaporg.[Accessed 20 September 2016].

xiii. Wood, Andrew, F., Smith \& Matthew, J., 2005. Online Communication: Linking Technology, Identity \& Culture.. London: Lawrence Erlbaum Associates. 